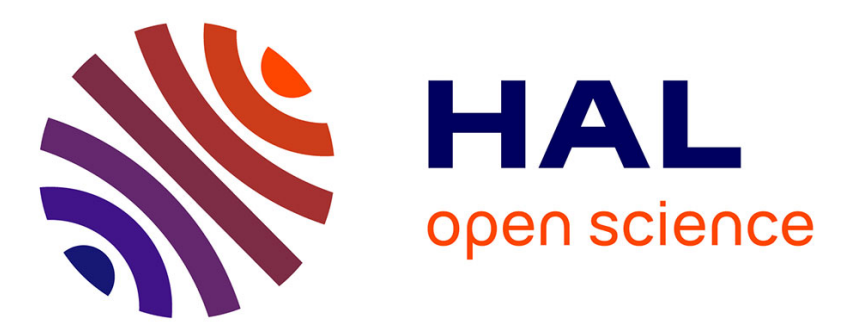

\title{
The function of surface fires in the dynamics and structure of a formerly grazed old subalpine forest
}

Aurélie Genries, Xavier Morin, Sandrine Chauchard, Christopher Carcaillet

\section{To cite this version:}

Aurélie Genries, Xavier Morin, Sandrine Chauchard, Christopher Carcaillet. The function of surface fires in the dynamics and structure of a formerly grazed old subalpine forest. Journal of Ecology, 2009, 97 (4), pp.728-741. 10.1111/j.1365-2745.2009.01518.x . hal-02660428

\section{HAL Id: hal-02660428 \\ https://hal.inrae.fr/hal-02660428}

Submitted on 30 May 2020

HAL is a multi-disciplinary open access archive for the deposit and dissemination of scientific research documents, whether they are published or not. The documents may come from teaching and research institutions in France or abroad, or from public or private research centers.
L'archive ouverte pluridisciplinaire HAL, est destinée au dépôt et à la diffusion de documents scientifiques de niveau recherche, publiés ou non, émanant des établissements d'enseignement et de recherche français ou étrangers, des laboratoires publics ou privés. 


\title{
The function of surface fires in the dynamics and structure of a formerly grazed old subalpine forest
}

\author{
Aurélie Genries $^{1,2 *}$, Xavier Morin ${ }^{1,2}$, Sandrine Chauchard ${ }^{1,2}$ and Christopher Carcaillet ${ }^{1,2}$ \\ ${ }^{1}$ Centre for Bio-Archeology and Ecology (UMR5059 CNRS), Université Montpellier 2, Institut de Botanique, 163 rue \\ Broussonet, F-34090 Montpellier, France; and ${ }^{2}$ Paleoenvironments and Chronoecology (PALECO, EPHE), Institut de \\ Botanique, 163 rue Broussonet, F-34090 Montpellier, France
}

\begin{abstract}
Summary
1. Changes in the frequency and intensity of disturbances are expected to occur during the coming decades as a consequence of climatic changes. Mountain forests are sensitive to climate variability, disturbances and changes in human activities; this is particularly true for subalpine forests located close to the limits of tree-growth. Here we test the role of surface fires on the structure and the dynamics of a subalpine forest compared to a control stand not affected by fire events for at least two centuries.

2. The fire events are deduced from fire scars, the age-structure from tree-ring counting, regeneration from sapling and seedling counts, necromass from the volume of woody debris, and the understorey structure from shrub and herb cover, height and biomass. Land-use history is assessed from livestock and human inventories.

3. Four surface fires occurred during the last 200 years in the burned stand. Tree density is greater in the burned stand, and, even 50 years after the last fire, burning could still be having a positive effect on regeneration density. Land-use history, mainly grazing by cattle and sheep, explains the modern forest structure through its promotion of Larix decidua. The understorey composition is the same within the two stands, suggesting a rapid recovery of dwarf shrubs (Rhododendron ferrugineum and Vaccinium myrtillus) after the latest fire, which coincided with the final change in land-use. The exception is $V$. vitis-idaea cover, which is higher in the control stand. The removal of livestock in the 1940s indirectly triggered a decline in L. decidua regeneration, which was formerly promoted by grazing and trampling. Conversely, Pinus cembra seedlings have begun to establish during the last 70 years.

4. Synthesis. Expansion of forests dominated by P. cembra is expected during the 21 st century, unless current global warming leads to a significant and lethal increase in fire frequency, that is, a reduction of fire-return intervals, which would reduce the number of sexually mature trees. The re-introduction of grazing could maintain the mixed subalpine forests, whereas surface fires would alter the woody debris load, promoting greater regeneration of L. decidua and P. cembra.
\end{abstract}

Key-words: biomass, data inventories, disturbance, dwarf shrubs, fire, grazing abandonment, Larix decidua, Pinus cembra, tree dynamics, woody debris

\section{Introduction}

Increases in the frequency and intensity of natural and anthropogenic disturbances are expected to occur in the coming decades as a consequence of global climate changes (Schär et al. 2004; Schröter et al. 2005; Thuiller et al. 2005; IPCC 2007). Temperate forests, in particular subalpine forests that are found close to the tree line, are sensitive to climate

*Correspondence author. E-mail: aurelie.genries@univ-montp2.fr variability (Morin et al. 2007), disturbances and land-use changes (Grace et al. 2002; Price 2003; Scheller \& Mladenoff 2005). Such subalpine forests could be especially sensitive to more pronounced global climatic changes (Gale 1986; Graumlich 1991; Gehrig-Fasel et al. 2007), and, as a consequence of these changes, to an increase in the frequency of disturbances (Schumacher \& Bugmann 2006).

In Europe, although the upper subalpine forests dominated by Pinus cembra L., Pinus mugo Turra or Larix decidua Mill. are classified as key habitats (European Commission DG 

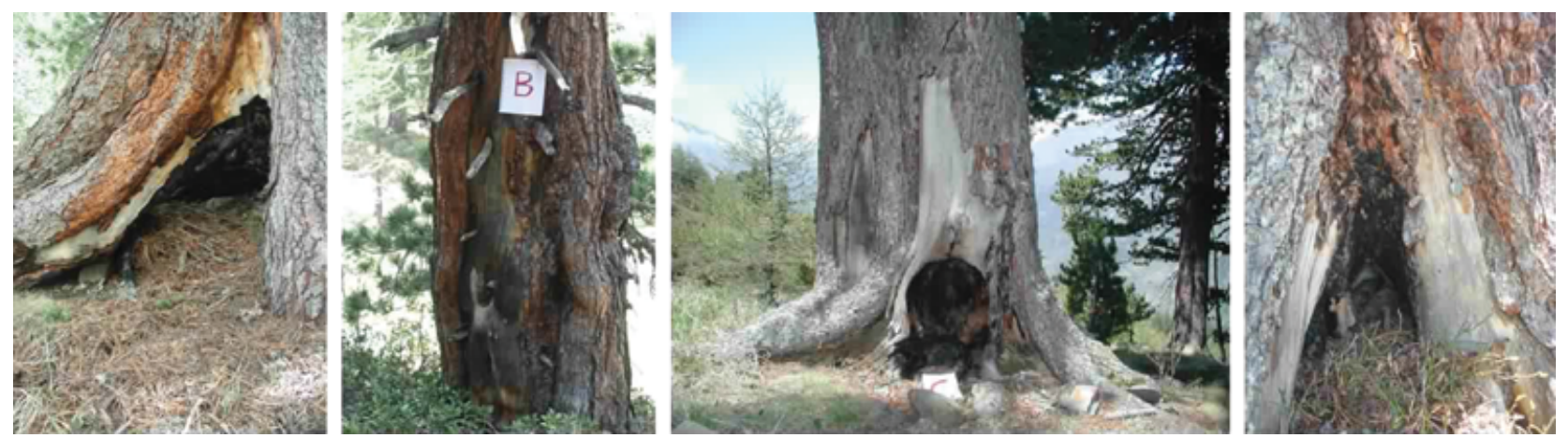

Fig. 1. Examples of fire scars recorded in the burned stand at Lanslevillard.

Environment 2003), little is known about their functioning, in terms of structure and dynamics. However, since the middle of the 19th century, forest landscapes have been transformed as a result of changes in forestry practices, and the cessation of traditional agro-pastoral activities; this has included land abandonment (Jail 1969) and grazing cessation (Barbero et al. 1990; Didier 2001; Motta et al. 2006b). The abandoned subalpine pastures were rapidly colonized by $L$. decidua or P. mugo, followed by massive regeneration of P. cembra (e.g. Piussi 1994; Krüsi \& Moser 2000; Didier 2001). Significant decreases in tree and sapling densities of shade-intolerant trees have been observed since 1950s (Risch et al. 2003). Subalpine forests experienced strong modifications although the kinetics of forest dynamics are slow because forests are slowgrowing ecosystems. Although world-wide, fire is recognized as having a major effect on terrestrial ecosystems (Wright 1974; Bond et al. 2005), little is known about the consequences of fire in mountain ecosystems, because for centuries these forests were cut and fire was indirectly suppressed for agricultural purposes. However, several studies have shown that fires did occur during the last millennia in the European mountains (Carcaillet 1998; Tinner et al. 1999), and that their occurrence could increase during the 21 st century as a result of global warming (Beniston 2000).

In the French Alps, during the Holocene, fires were asynchronous, with similar frequency patterns between 9000 and 4500 cal. years BP but not after this period (Carcaillet et al. 2009). Paleoecological studies have shown that wildfires occurred at moderate frequencies within the P. cembra-dominated forests during the early- and middle-Holocene (Genries et al. 2009b); when fires were more frequent, plant composition (Genries et al. 2009a) and soil quality (Mourier 2008) were affected for several centuries. Nevertheless, the impact of fires on forest structure and species composition of these systems still needs to be deciphered. It is especially crucial to understand how the stand structure and development of subalpine forests may change in response to environmental modifications, such as a disruptive fire regime (disturbance) or the cessation of grazing (stress). Two complementary approaches were taken.

First, we hypothesized that fires could affect the accumulation of woody debris (WD) or shrub biomass (and thus the fuel-load), altering the risk of new fires spreading and promoting tree regeneration. To test this hypothesis, we compared a burned stand and a neighbouring control. We quantified the ecological consequences of fires on forest structure in terms of regeneration, living biomass, WD and thickness of the litter and humus layers. Fire scars on $P$. cembra trunks were used as fire proxies (Fig. 1).

Second, we differentiated between the impact of fires and land-use change on the establishment and the age-structure of tree populations, based on tree-ring data and inventories of the human population and livestock.

The ultimate aim of our study was to identify possible approaches to manage the mountain forests, taking into account fire as a process resulting from both land-use and climatic changes.

\section{Methods}

\section{STUDY SITE}

The forest is located at $45^{\circ} 17^{\prime} 20^{\prime \prime} \mathrm{N}, 6^{\circ} 57^{\prime} 07^{\prime \prime} \mathrm{E}$, approximately $2150 \mathrm{~m}$ a.s.l. within the district of Lanslevillard in the upper Maurienne Valley (Savoy, central French Alps; Fig. 2). This valley is located along the French-Italian border, at the northern limit of any Mediterranean climatic influence and is one of the driest areas of the Alps. The mean annual precipitation and air temperature are $884 \pm 167 \mathrm{~mm}$ and $3.5 \pm 0.6^{\circ} \mathrm{C}$, respectively (Bessans meteorological station, $1715 \mathrm{~m}$ a.s.l.). The mean temperatures for the coldest (January) and the warmest (July) months are $-6.5 \pm 1.8$ and $13.7 \pm$ $1.3{ }^{\circ} \mathrm{C}$, respectively.

At the turn of the 18th century, the upper Maurienne Valley was entirely used for agriculture (Delcros 1994). Former land uses include cattle, mule and sheep husbandry and cultivation for haymaking; large areas were therefore meadows. Land abandonment began at the end of the 19th century (Jail 1969) and resulted in significant vegetation change leading to forest establishment and subsequently to the introduction of a fire-suppression policy. Today, the lower subalpine belt (c. 1700-1900 m a.s.1.) is covered by open coniferous woodlands dominated by Pinus sylvestris L., L. decidua and Picea abies (L.) H. Karst and an understorey characterized by Vaccinium spp., Arctostaphylos uva-ursi (L.) Sprengel, Juniperus communis L. and Ononis rotundifolia $\mathrm{L}$., or by shrublands composed of tall and dwarf shrubs (Betulaceae, Ericaceae, Salicaceae). Above $1900 \mathrm{~m}$ a.s.l., the upper subalpine forests are dominated by P. cembra, 


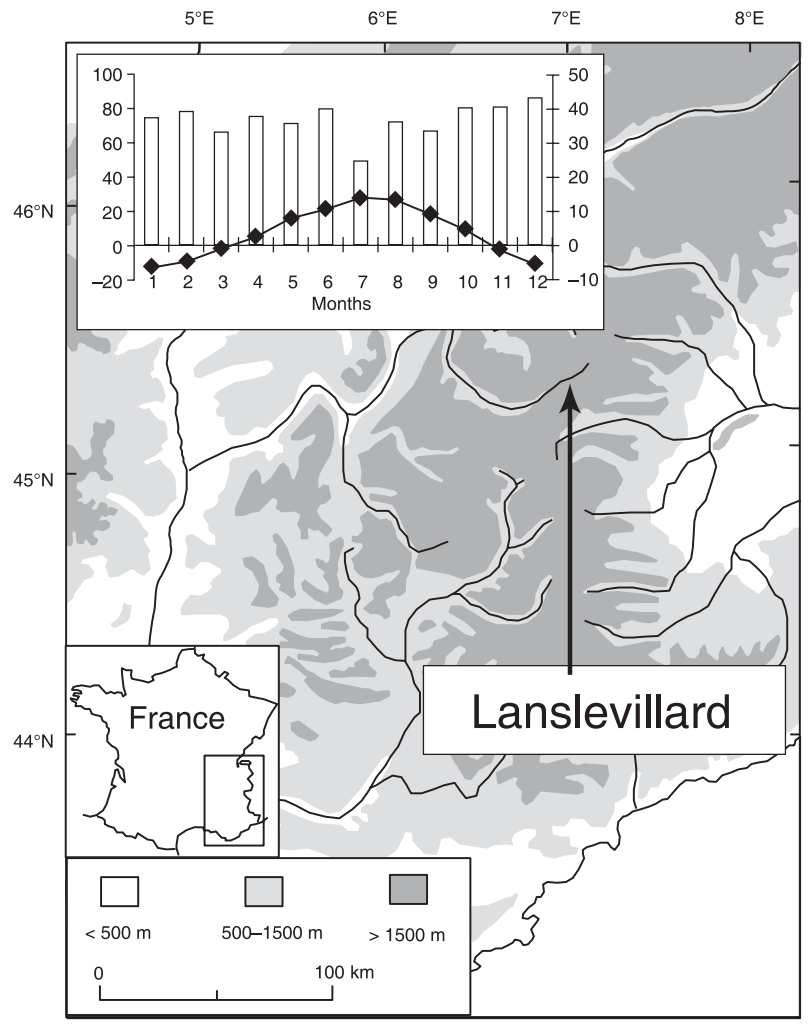

Fig. 2. Location of the study site in the Maurienne valley, French Alps. The inset graph is an ombrothermic diagram, in which the histograms represent mean monthly precipitation (right axis) and the diamonds mean monthly temperatures.
P. mugo, L. decidua, and P. abies, with understoreys of Juniperus sibirica Loddiges ex Burgsdorff, Vaccinium spp. and Rhododendron ferrugineum. The upper tree line reaches 2350-2400 m a.s.l. (Bartoli 1966). The alpine belt (> $2300 \mathrm{~m}$ a.s.l.) is covered with boulders and species-rich short-grass meadows characterized by Carex curvula All. and Nardus stricta L.

\section{SAMPLING DESIGN FOR FLORISTIC AND BIOMASS INVENTORIES}

In June and July 2006, we sampled two contiguous stands of $8000 \mathrm{~m}^{2}$ each $(80 \times 100 \mathrm{~m})$, one burned and one control. The stands are separated by a trekking path and the burned stand is located above the control one. They have the same soil type (podzolic), aspect $(\mathrm{N}-\mathrm{NW})$ and slope $\left(23^{\circ}\right)$. Scattered trees with fire scars allowed us to delimit the burned stand.

Each stand was analysed at the stand and plot scales. Each stand contained three transects of $25 \mathrm{~m}$ and 10 plots measuring $100 \mathrm{~m}^{2}$ each, evenly distributed across the area. Each plot contained four 3 -m-radius circles, five quadrats measuring $2 \times 5 \mathrm{~m}$ and one quadrat of $1 \mathrm{~m}^{2}$ (Fig. 3).

1.a. At the stand scale $\left(8000-\mathrm{m}^{2}\right)$, for trees with $\varnothing \geq 5 \mathrm{~cm}$ at a height of $30 \mathrm{~cm}$, within both stands, we described canopy characteristics at the $8000-\mathrm{m}^{2}$ stand scale, that is, number of trees, tree species and diameter at $30 \mathrm{~cm}$, in order to calculate density and basal area per stand and per species (McRae et al. 1979). These trees were cored with an increment borer at around $30 \mathrm{~cm}$ above the ground to determine their age by counting the annual growth rings; this provided us with data on the age structure of the populations, which mirrors forest dynamics.

1.b. The necromass volume was estimated by tallying the WD (method adapted from Motta et al. 2006a). WD was classified into

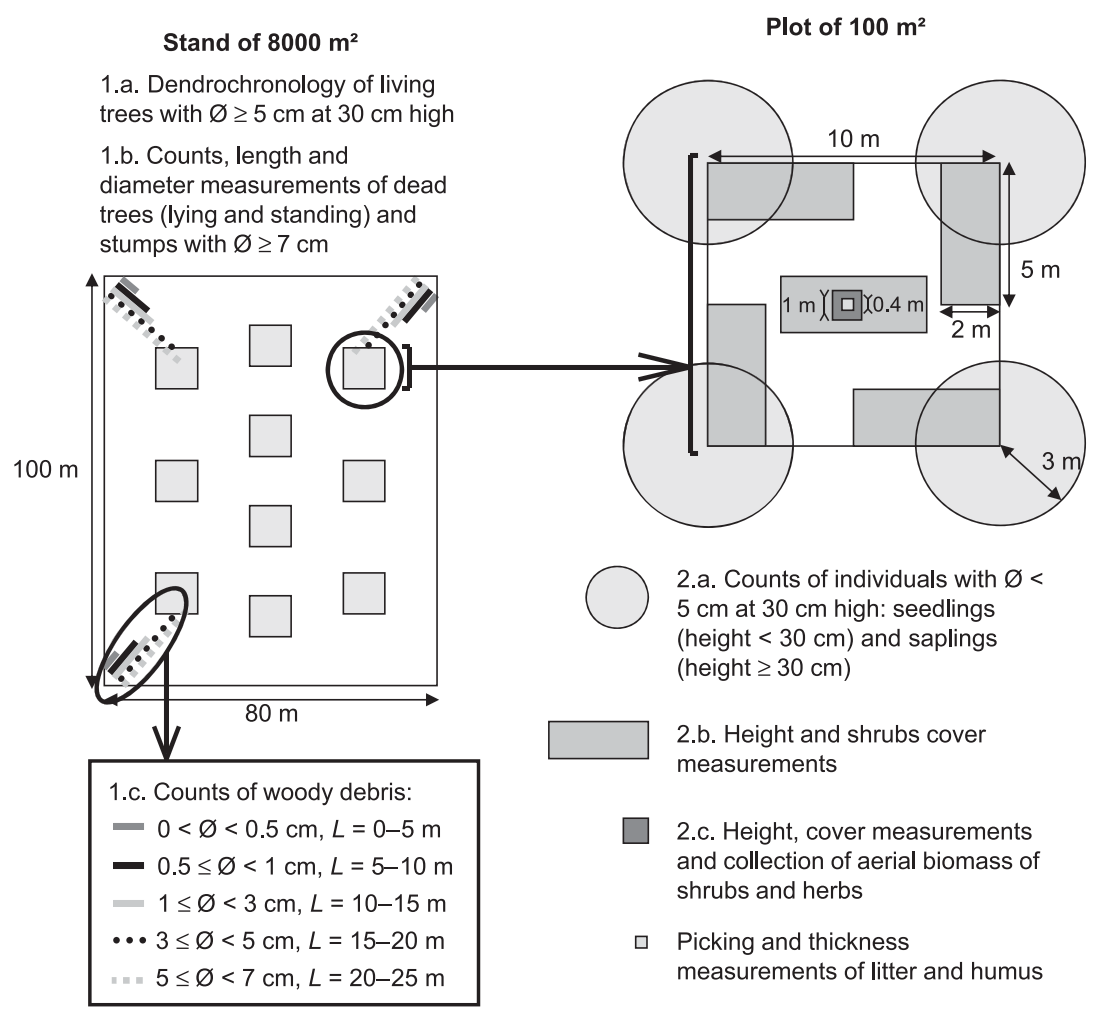

Fig. 3. Design of the field sampling strategy. The bold numbers refer to the corresponding numbers in the 'Methods' section. 
small (diameter $(\varnothing)<7 \mathrm{~cm})$ and large $(\varnothing>7 \mathrm{~cm}) \operatorname{logs}$ (fallen stems or branches), snags (dead standing trees, $\varnothing>7 \mathrm{~cm}$ and height $\geq 1 \mathrm{~m}$ ) and stumps (short, vertical trunks created by cutting or wind throw, top- $\varnothing>7 \mathrm{~cm}$ and height $\leq 1 \mathrm{~m}$ ). Snags were distinguished from logs by their angle: where the angle with the ground was more than $45^{\circ}$ the object was classified as a snag. The volume of snags and large logs was estimated as a frustum of a double cone from the radius at ground level (avoiding roots or irregular shapes) and the length:

$V_{\mathrm{SLL}}=\frac{\pi}{3} 2 R^{2} L$

where $V_{\mathrm{SLL}}$ is the volume of the snags and large $\operatorname{logs}\left(\mathrm{m}^{3}\right), R$ is the radius of the larger end $(\mathrm{m})$ and $L$ is the length of the snag or large $\log (\mathrm{m})$. The volume of stumps was estimated as a frustum of a cone from the diameter at the top, the diameter at ground level (avoiding roots or irregular shapes) and height, estimating a plane cutting off the apex, parallel to the base (Motta et al. 2006a):

$V_{s}=\left[\frac{S_{0}+S_{t}}{2}\right] L$

where $V_{s}$ is the volume of the stump $\left(\mathrm{m}^{3}\right), S_{\mathrm{t}}$ is the area of the smaller end $\left(\mathrm{m}^{2}\right), S_{0}$ is the area of the larger end $\left(\mathrm{m}^{2}\right)$ and $L$ the length $(\mathrm{m})$.

1.c. Fine WD was quantified by the line-intersect method (adapted from Van Wagner 1982), applied to three series of transects. Woody fragments were classified into the five diameter classes recommended by McRae et al. (1979); the original classification was developed for boreal forest, a close analogue of subalpine forest. Different intersect-line lengths were used for each diameter class: class I, [0-0.5] cm along a 5-m transect; class II, [0.5-1] $\mathrm{cm}$ along a $10-\mathrm{m}$ transect; class III, [1-3] cm along a 15-m transect; class IV, [3-5] cm along a 20-m transect; class $\mathrm{V}$, [5-7] $\mathrm{cm}$ along a 25-m transect (Fig. 3; Hély et al. 2000a,b). The equation to calculate the volume is adapted from Brown (1974) modified by Van Wagner (1982), as follows:

$V_{\mathrm{SWD}}=\frac{k}{L} \sum d a c$

where $V_{\text {SWD }}$ is the volume of fine WD $\left(\mathrm{m}^{3}\right), k$ is a constant with a value of 1.234 (Van Wagner 1982), $L$ is the length of the transect (m), $d$ is the fragment diameter at the intersection with the transect line $(\mathrm{cm}), a$ is a correction factor for non-horizontal debris, that is a value of 1.13 (Brown 1974), and $c$ is a slope correction factor (Brown 1974) computed from the slope angles of each stand.

2.a. At the plot scale (100- $\mathrm{m}^{2}$, Fig. 3), within the four 3-m-radius circles, all tree species seedlings (height $<0.3 \mathrm{~m}$ ) and saplings (height $\geq 0.3 \mathrm{~m}, \varnothing<5 \mathrm{~cm}$ at $30 \mathrm{~cm}$ high) were counted to quantify recent regeneration.

2.b. Within each plot, five $10 \mathrm{~m}^{2}$-quadrats $(2 \times 5 \mathrm{~m})$ were used to quantify the height, the species-richness and the cover of shrubs. The cover was estimated on the basis of the six categories of Van der Maarel's cover-index (Van der Maarel 1979).

2.c. At the centre of the plot, one quadrat of $1 \mathrm{~m}^{2}(1 \times 1 \mathrm{~m})$ was delineated (Fig. 3) in order to estimate the cover of herbs. Furthermore, exhaustive sampling of shrub and herb species was conducted to characterize the understorey biomass. Finally, the thickness of the litter and humus layers was measured in a $0.4 \times 0.4 \mathrm{~m}$ quadrat included in the previous one, and samples of both layers were collected for dry mass measurements.

To predict shrub biomass using a non-destructive method, allometric equations were derived from linear and power models, taking into account plant cover and above-ground height, using the data from the $1 \mathrm{~m}^{2}$ quadrats. Parameter estimates were derived by simulated annealing using the Metropolis algorithm (Metropolis et al. 1953). This algorithm allows exploration of the parameter space to ensure convergence towards the absolute least-square minimum (details in Chuine et al. 1998). These models were constructed using Delphi 6.0 software (Borland ${ }^{\mathrm{TM}}$ ). Different models were tested, including linear and power relationships, and a power model was finally chosen for each species. Finally, the allometric equations were applied to all measurements of height and cover over the larger area of $500 \mathrm{~m}^{2}$ for each stand, allowing estimation and comparison of the shrub biomass in all quadrats.

\section{TREE AGE DETERMINATION}

Cores were mounted, air-dried and smoothed using progressively finer sand paper in order to make the annual growth rings readily visible. To determine tree age, tree rings were counted and cross-dated by visual observation under a dissecting microscope $(40 \times$ or $60 \times)$. For incomplete cores where the pith was not sampled, we estimated the length of the missing radius by matching the curvature of the innermost rings to concentric circles drawn on paper (Applequist 1958; Arno \& Sneck 1977). The number of years to the pith was then estimated by calculating the mean number of tree-rings on radii of corresponding lengths from 739, 239 and 14 complete cores of P. cembra, L. decidua and P. abies, respectively; these data were taken from Beilhe et al. (2009), who collected their data in the same area. To estimate total age, the number of years taken to reach coring height has to be added to the age previously obtained. This number of years was derived from Beilhe et al. (2009), and was assessed by determining the height-age relationship of seedlings and saplings (Mast et al. 1998; Kajimoto et al. 2002; Chauchard et al. 2007). Heights (ln-transformed) were plotted against ages and, a linear regression model was used for modelling the height-age relationship. Total age was obtained by adding our estimates of age at coring height to the estimated number of years required to reach $30 \mathrm{~cm}$, as determined using the equations in Table 1.

The method provides estimated tree ages closer to real ages and assumes that the growing conditions of extant seedlings and samplings are similar to those experienced by canopy trees. Whatever the accuracy of this assumption, the age estimates obtained by this method are more appropriate than simply using age at coring height to compare the tree age-structure with the human or livestock inventories.

\section{STATISTICS AND MODELLING}

To reduce errors introduced by the procedure for estimating tree age, age-structure was plotted using 10-year classes. Because our data did not exhibit a normal distribution $\left(\chi^{2}\right.$ test, $P$-value $\left.<0.01\right)$, we used the nonparametric Kolmogorov-Smirnov test (KS-test) to examine

Table 1. Allometric equations derived from Beilhe et al. (2009) to calibrate the missing years when estimating tree-ages from a tree-ring core at $30 \mathrm{~cm}$ height, where $x$ is the tree-age and $y$ is the $\ln$-transformed height value. $n$ is the sapling number used to produce the model

\begin{tabular}{llll}
\hline & $\begin{array}{l}\text { Sampling } \\
\text { numbers }(n)\end{array}$ & Equation & $\begin{array}{l}\text { Age at } \\
30 \mathrm{~cm}( \pm \mathrm{SD})\end{array}$ \\
\hline Pinus cembra & 665 & $y=0.19 x+4.7$ & $10 \pm 5$ \\
Larix decidua & 144 & $y=0.15 x+8.22$ & $13 \pm 9$ \\
Picea abies & 23 & $y=0.15 x+12.34$ & $17 \pm 7$ \\
\hline
\end{tabular}


Table 2. Stand characteristics. Only cored individuals are reported ( $\varnothing>5 \mathrm{~cm}$ at $30 \mathrm{~cm} \mathrm{high)}$

\begin{tabular}{|c|c|c|c|c|c|c|}
\hline & \multirow[b]{2}{*}{ Species } & \multirow{2}{*}{$\begin{array}{l}\text { Number of } \\
\text { individuals }\end{array}$} & \multicolumn{2}{|c|}{ Density of individuals } & \multicolumn{2}{|c|}{ Basal area } \\
\hline & & & Number ha ${ }^{-1}$ & $\%$ & $\mathrm{~m}^{2} \mathrm{ha}^{-1}$ & $\%$ \\
\hline \multirow[t]{4}{*}{ Burned stand } & Pinus cembra & 145 & 181 & 40.7 & 17 & 50.1 \\
\hline & Larix decidua & 201 & 251 & 56.5 & 17 & 49.3 \\
\hline & Picea abies & 10 & 12 & 2.8 & $<1$ & 0.6 \\
\hline & Total & 356 & 444 & 100 & 34 & 100 \\
\hline \multirow[t]{4}{*}{ Control stand } & Pinus cembra & 82 & 102 & 46.1 & 13 & 51.4 \\
\hline & Larix decidua & 80 & 100 & 44.9 & 11 & 43.3 \\
\hline & Picea abies & 16 & 20 & 9.0 & 1 & 5.3 \\
\hline & Total & 178 & 222 & 100 & 25 & 100 \\
\hline
\end{tabular}

differences in age distributions between burned and control stands. This test was first applied to raw data and then to data standardized as follows $\left(z_{s i}\right)$ :

$$
Z_{s i}-\frac{x_{s i}-\bar{x}_{s}}{\sigma_{s}}
$$

where $x_{s i}$ is the number of individuals of species $s$ in the $i$ th age-class, and $\bar{x}_{s}$ and $\sigma_{s}$ are the mean number and the SD of $s$ over the whole sequence, respectively.

The nonparametric Mann-Whitney test allows data series to be compared when they do not adhere to the criteria for normality; we used it to test differences between the burned and control stands with respect to: i) the number of $P$. cembra seedlings $(h<10 \mathrm{~cm})$; ii) the number of $P$. cembra saplings $(10 \mathrm{~cm}<h<30 \mathrm{~cm})$; iii) the number of $L$. decidua saplings; iv) the percentage cover and the height of R. ferrugineum, V. myrtillus and V. vitis-idae $\mathrm{L}$.; v) the number of shrub species; vi) the number of herb species; vii) the mass of herbs; and viii) the mass and the depth of litter and humus layers.

\section{DATA INVENTORIES OF HUMAN POPULATIONS AND LIVESTOCK}

As a first approximation, we assumed that human populations and livestock numbers can be considered as proxies for land-use pressures on vegetation (Chauchard et al. 2007). The cumulated number of permanent inhabitants and transient shepherds in the three villages closest to the study site (Lanslebourg, Lanslevillard, Bessans) were obtained from http://cassini.ehess.fr and from the Archives Départementales de Savoie (archive number C580-C606-608, Département de Modane) combined with data from Jail (1969). The number of cattle and sheep in the upper Maurienne Valley was obtained from Jail (1969). The trajectories for the cumulated number of trees on the two stands were compared with the number of inhabitants and transient shepherds in the three villages mentioned above and with the number of sheep and cattle in the upper Maurienne Valley.

\section{Results}

FIRE DATES, TREE-STAND CHARACTERISTICS AND AGE STRUCTURES

Within the burned stand, six P. cembra have fire-scars (Fig. 1). Four fire events were identified and dated by tree-ring counting (Fig. 4). The fires occurred in 1833, 1887, 1894 and 1954 (Fig. 4).
Of the six trees, two have scars corresponding to two fire events. No scars were visible on old-growth $L$. decidua or P. abies.

In total, 534 trees were cored, majority were in the burned stand, that is $67 \%$ of the total (Table 2). Of the 356 trees cored from the burned stand and the 178 from the control stand, 28 and 17 , respectively, were not dated because they had rotten centres. In both burned and control stands, the majority of trees were $P$. cembra or L. decidua; the most efficient tree recruitment occurred between 1920 and 1940 (Fig. 4). The only other tree species present was $P$. abies (Table 2), for which recruitment never exceeded three trees per 10-year class (Fig. 4). The oldest dated tree was a 419-year-old L. decidua tree of and the youngest trees, that is, $<60$ years old, were mostly P. cembra (Fig. 4). Very few L. decidua were $<60$ years old.

The age structures based on total tree numbers indicate a significant difference between the burned and control stand (KS-test, $P$-value $<0.01$ ), but there is no difference when the tree numbers are standardized (KS-test, $P$-value $>0.10$ ). The standardized age structures show the trends in tree population dynamics irrespective of the unit of tree abundance and without effect on the variation profile. In both the burned and control stand, similar phases of tree recruitment were found (Fig. 4). Between 1660 and 1730, there was a slight increase in tree number, from 4 to 18 individuals in total. This was followed by a decrease over the subsequent 50 years, with only a total of three trees dated from 1775. Recruitment then increased again until 1835, before the number of trees in both stands stabilized. The increase in numbers from 1890 to 1940 was large, with a maximum of 52 trees per 10 years for the two stands combined; this was recorded for the period 19201930. Since 1940, the recruitment in both stands has dropped continuously, with only one tree recorded during the last decade.

\section{SEEDLING AND SAPLING REGENERATION PATTERNS}

In both stands, the only seedlings recorded were $P$. cembra: 840 seedlings $\mathrm{ha}^{-1}$ in the burned stand and 150 seedlings ha $\mathrm{h}^{-1}$ in the control stand (Table 3 ). Most of the saplings were P. cembra in both the burned (292 saplings ha ${ }^{-1}$ ) and control (80 saplings ha ${ }^{-1}$ ) stand, but there were a few L. decidua and Abies 
(a)

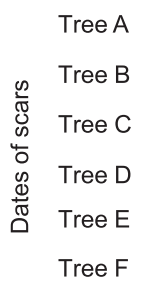

(b)

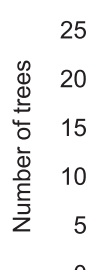

- Pinus cembra

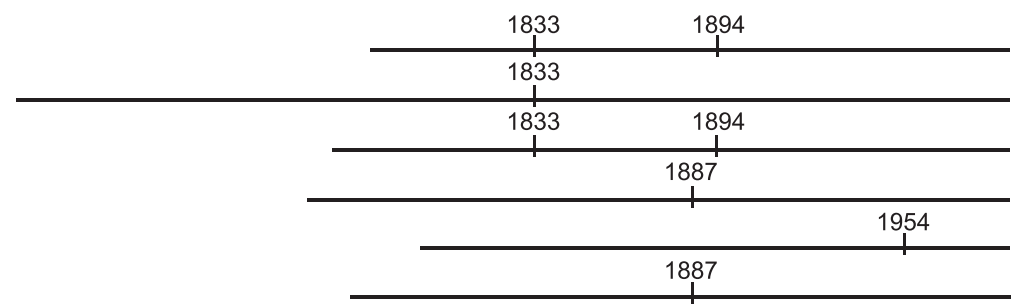

L Larix decidua

口Picea abies

Burned stand

Burned stand
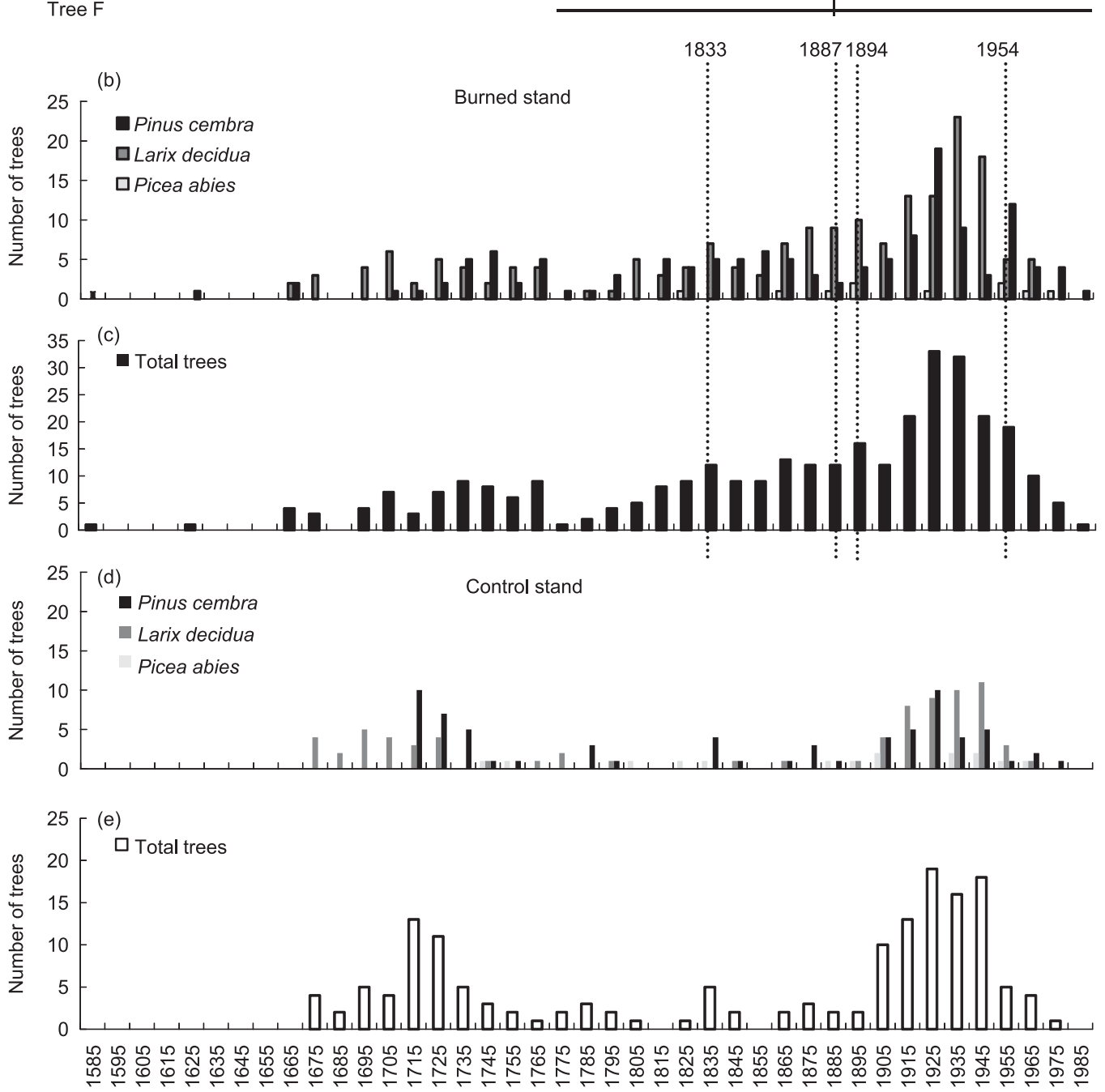

Year of regeneration (10-year classes)

Fig. 4. (a) Dates of the fire scars on the six burned trees. Age-class structure of individuals $\varnothing>5 \mathrm{~cm}$ at $30 \mathrm{~cm}$ high for (b) Pinus cembra, Larix decidua and Picea abies in the burned stand, (c) all tree species combined in the burned stand $(n=328)$, (d) Pinus cembra, Larix decidua and Picea abies in the control stand, and (e) all tree species combined in the control stand $(n=161)$. Dotted lines correspond to the fires. Dates on the $x$-axis correspond to the median dates of the 10-year class, for example, 1925 for [1920-1930].

alba L. saplings in the burned stand (35 and 9 saplings ha ${ }^{-1}$, respectively) and $L$. decidua and $P$. abies saplings in the control stand (27 and 9 saplings ha ${ }^{-1}$, respectively) (Table 3). The mean numbers of $P$. cembra seedlings and saplings and L. decidua saplings were not statistically different in the two stands because of large variances (Fig. 5a,c,e). However, there were significantly more $P$. cembra seedlings and saplings per hectare in the burned stand than the control (Fig. 5b,d). These data indicate that $P$. cembra regeneration is more spatially heterogeneous in the burned stand.

\section{UNDERSTOREY STRUCTURE AND COMPOSITION}

The mean cover of $R$. ferrugineum and $V$. myrtillus was similar in the two stands, but there were significant differences in the cover of $V$. vitis-idaea between the two (Table 3; Fig. 6a,c,e). In fact, approximately $30 \%$ of the $10-\mathrm{m}^{2}$ quadrats did not contain $V$. vitis-idaea in the burned stand, and approximately $30 \%$ of plots had $<5 \%$ cover in the control (Table 3; Fig. 6 ). Rhododendron ferrugineum and V. myrtillus were the only species with cover values exceeding $50 \%$ of the sampled areas (Table 3; 
Table 3. Mann-Whitney tests on the differences between the burned stand and the control stand. The bold $P$-values indicate significant differences $(P<0.05)$; asterisks indicate the two parameters that were not tested because there were too few seedlings or saplings (only one spruce and one fir sapling recorded)

\begin{tabular}{|c|c|c|c|c|}
\hline & Burned stand & & Control stand & $P$-value \\
\hline \multicolumn{5}{|l|}{ Seedlings (number ha ${ }^{-1}$ ) } \\
\hline Pinus cembra & $840 \pm 1855$ & $>$ & $150 \pm 348$ & 0.045 \\
\hline \multicolumn{5}{|l|}{ Saplings (number ha ${ }^{-1}$ ) } \\
\hline Pinus cembra & $292 \pm 431$ & $>$ & $80 \pm 233$ & 0.014 \\
\hline Larix decidua & $35 \pm 108$ & - & $27 \pm 94$ & 0.851 \\
\hline Abies alba* & $9 \pm 56$ & - & 0 & no test \\
\hline Picea abies* & 0 & - & $9 \pm 56$ & no test \\
\hline \multicolumn{5}{|l|}{ Richness (number of species) } \\
\hline shrubs quadrat $^{-1}$ & $3.53 \pm 0.91$ & - & $3.41 \pm 0.73$ & 0.293 \\
\hline herbs $\mathrm{m}^{-2}$ & $5.40 \pm 2.59$ & - & $5.10 \pm 1.97$ & 0.940 \\
\hline \multicolumn{5}{|l|}{ Cover (Van der Maarel index) } \\
\hline Rhododendron ferrugineum & $2.51 \pm 1.62$ & - & $2.59 \pm 1.40$ & 0.759 \\
\hline Vaccinium myrtillus & $2.88 \pm 1.61$ & - & $3.18 \pm 0.95$ & 0.158 \\
\hline Vaccinium vitis-idaea & $0.76 \pm 1.13$ & $<$ & $1.47 \pm 1.04$ & 0.004 \\
\hline \multicolumn{5}{|l|}{ Height $(\mathrm{cm})$} \\
\hline Rhododendron ferrugineum & $46.07 \pm 12.95$ & - & $43.14 \pm 9.88$ & 0.310 \\
\hline Vaccinium myrtillus & $29.77 \pm 7.31$ & - & $31.94 \pm 9.51$ & 0.186 \\
\hline Vaccinium vitis-idaea & $10.89 \pm 2.45$ & - & $10.80 \pm 6.88$ & 0.229 \\
\hline Litter & $2.20 \pm 0.95$ & - & $1.72 \pm 0.91$ & 0.308 \\
\hline Humus & $3.50 \pm 1.37$ & - & $3.50 \pm 1.32$ & 0.967 \\
\hline \multicolumn{5}{|l|}{$\operatorname{Mass}\left(\mathrm{g} \mathrm{m}^{-2}\right)$} \\
\hline Rhododendron ferrugineum & $294 \pm 385$ & - & $220 \pm 139$ & 0.749 \\
\hline Vaccinium myrtillus & $120 \pm 72$ & - & $143 \pm 112$ & 0.967 \\
\hline Vaccinium vitis-idaea & $51 \pm 28$ & - & $51 \pm 36$ & 1.000 \\
\hline Litter & $271 \pm 254$ & - & $159 \pm 59$ & 0.112 \\
\hline Humus & $861 \pm 767$ & - & $1353 \pm 790$ & 0.089 \\
\hline Herbs & $194 \pm 124$ & - & $149 \pm 77$ & 0.545 \\
\hline
\end{tabular}

Fig. 6b,d). The above-ground biomass and height of the three main dwarf shrub species did not differ between the stands (Table 3; Fig. 7a-c). Similarly, the mean number of shrub and herb species and the mean mass of herbs were not significantly different between the stands (Table 3; Fig. 7d). Finally, both litter and humus layers had similar mean thicknesses and masses in the two stands (Table 3; Fig. 7e,f).

For the two main shrubs, the allometric equations to estimate plant biomass from plant cover and height are as follows; $R$. ferrugineum:

$M=\left(0.1034+3.0995 \times(C \times H)^{1.2419}\right) \times 20$ eqn 5

and V. myrtillus:

$M=\left(0.0237+0.5508 \times(C \times H)^{0.5545}\right) \times 20$ eqn 6

where $M$ is the above-ground dry mass $\left(\mathrm{kg} \mathrm{ha}^{-1}\right), C$ is the cover $\left(\mathrm{m}^{2}\right)$ and $H$ is the height $\left(\mathrm{m}^{2}\right)$. The relationships between the observed and the modelled dry masses of $R$. ferrugineum and V. myrtillus are significant with $r^{2}$ values of 0.94 and 0.57 , respectively (Fig. 8). These results demonstrate that accurate estimations of above-ground shrub biomass are possible on the basis of just plant cover and height. The allometric eqns 5 and 6, applied to all measurements of height and cover, thus allow us to estimate shrub biomass over the larger $500 \mathrm{~m}^{2}$ area for each stand. The estimated dry biomass of $R$. ferrugineum was greater on the burned stand $\left(3614 \mathrm{~kg} \mathrm{ha}^{-1}\right)$ than the control stand $\left(2783 \mathrm{~kg} \mathrm{ha}^{-1}\right)$; there was little difference between the stands for $V$. myrtillus (389 and $447 \mathrm{~kg} \mathrm{ha}^{-1}$, respectively).

\section{NECROMASS AND WOODY DEBRIS}

Figure 9 shows the volumes of WD in the two stands. Although these results cannot be tested statistically, they indicate that the volume of large downed logs, stumps and small downed logs is greater in the control stand than in the burned stand, whereas the volume of snags is almost the same in the two stands. The greatest difference appears to be associated with the large-downed logs, with $6.3 \mathrm{~m}^{3} \mathrm{ha}^{-1}$ in the burned stand and $87.7 \mathrm{~m}^{3} \mathrm{ha}^{-1}$ in the control stand. Table 4 shows that about two-thirds of all the stumps in the control stand and about a quarter in the burned stand were created by human activities.

Table 4. The proportion of cultural (sawn) and natural (wind throw) stumps in the burned and control stands

\begin{tabular}{|c|c|c|c|c|c|c|}
\hline & \multicolumn{2}{|c|}{ Sawn stumps } & \multicolumn{2}{|c|}{ Windthrows } & \multicolumn{2}{|l|}{ Total } \\
\hline & no ha ${ }^{-1}$ & $\%$ & no ha ${ }^{-1}$ & $\%$ & no ha ${ }^{-1}$ & $\%$ \\
\hline Burned stand & 4 & 7 & 11 & 31 & 15 & 17 \\
\hline Control stand & 50 & 93 & 25 & 69 & 75 & 83 \\
\hline Total & 54 & 100 & 36 & 100 & 90 & 100 \\
\hline
\end{tabular}



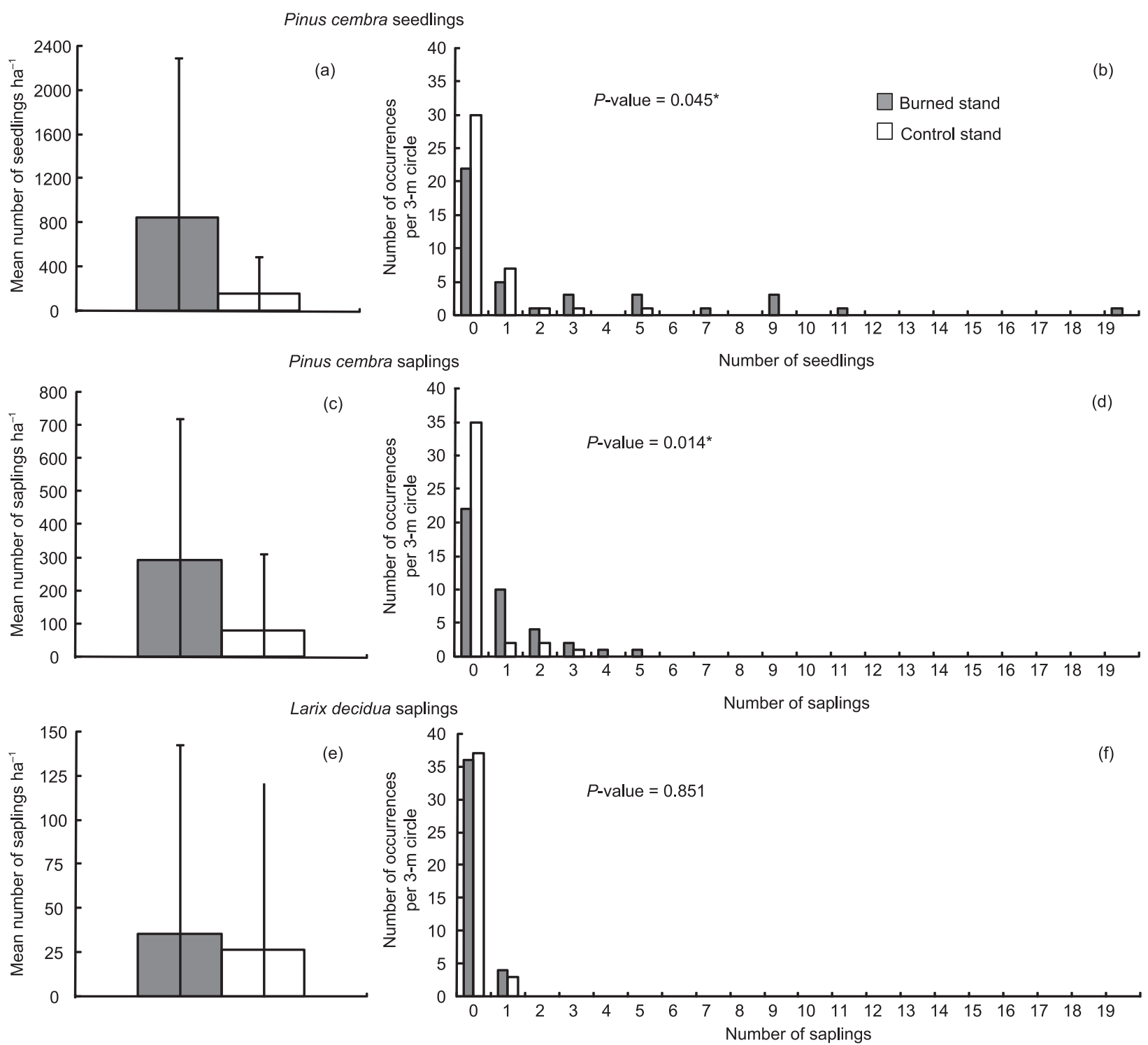

Fig. 5. Numbers of seedlings and saplings in the two stands: a,c,e) mean number of seedlings or saplings per hectare, b,d,f) number of times that each seedling or sapling count was recorded among all the samples. The asterisks $\left({ }^{*}\right)$ indicate significant differences between the stands (MannWhitney test; $P$-value $<0.05$ ).

\section{DATA INVENTORIES: HUMAN POPULATION AND LIVESTOCK}

Between 1790 and 1850, the numbers of sheep remained constantly high, and the numbers of human inhabitants and cattle increased, as did the cumulated number of trees on the burned and control stands (Fig. 10). Between 1850 and 1940, the number of livestock dropped (from 7700 to 2200 sheep and from 3800 to 2200 cattle), as did the numbers of permanent inhabitants and transient shepherds (from 3300 to 2000 people). Consistently, over the same period (1850-1940), the cumulated tree number increased. Since 1940, the recruitment of trees (i.e. individuals with $\varnothing \geq 5 \mathrm{~cm}$ at $30 \mathrm{~cm}$ high) and the numbers of inhabitants and cattle have decreased; in contrast, the number of sheep increased as a result of new agricultural practices during the 1990s, supported by French and EU policies aimed at sustaining mountain agriculture, especially sheep husbandry.

\section{Discussion}

\section{THE ROLE OF FIRE IN FOREST DYNAMICS AND COMPOSITION}

Judging from the fire scars found on trees in a formerly grazed mixed subalpine forest, fires were probably surface fires and probably enhanced tree regeneration in the burned stand. Fire scars (Fig. 1) on living P. cembra trees indicate that this species can survive several surface fires. Although we have no evidence relating to the origin of these fires, they were probably anthropogenic: stubble-burning has long been used by farmers to clear pastures. 

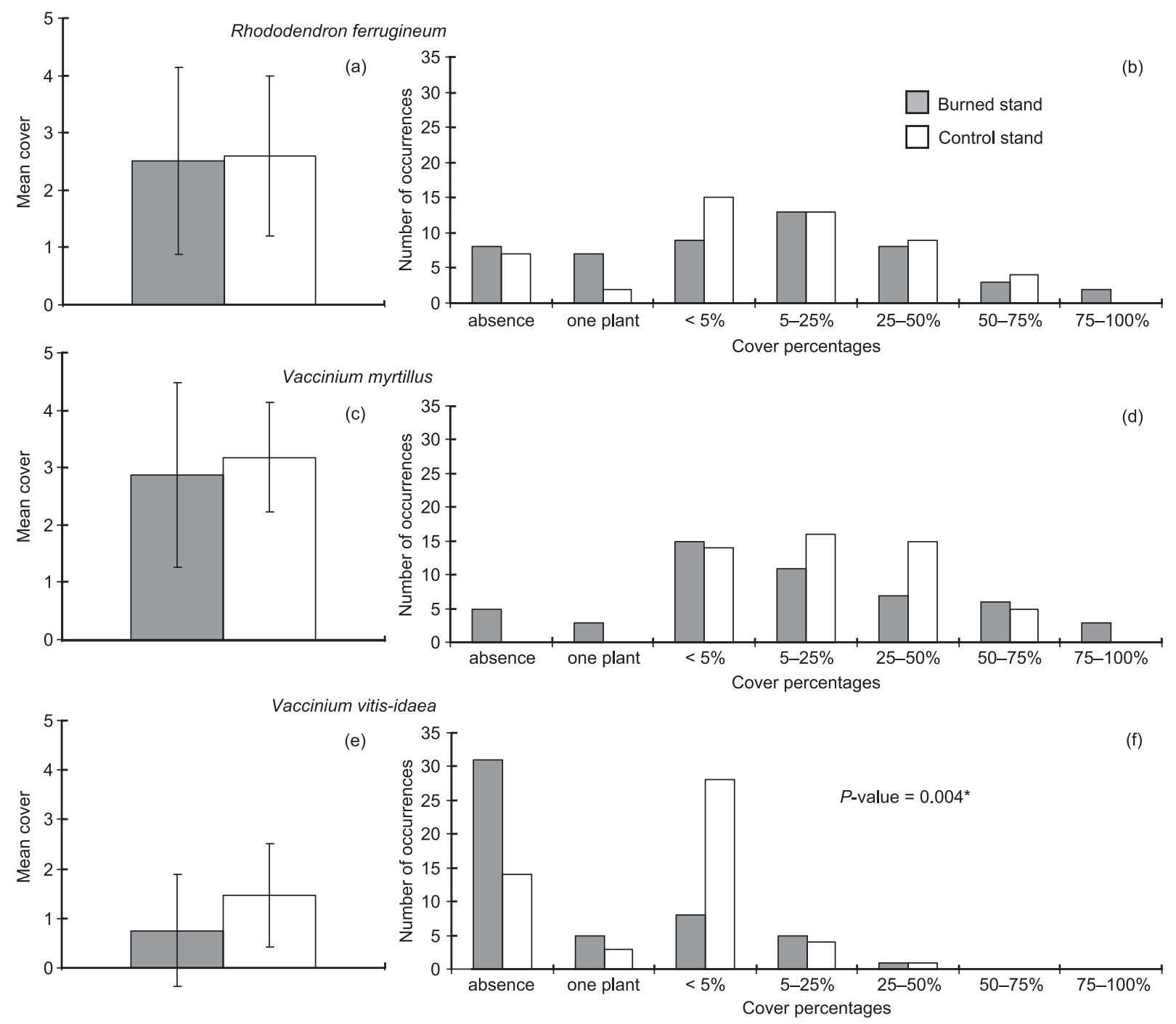

Fig. 6. Cover percentages of the three main shrubs species in the burned and control stands: a,c,e) mean cover (Van der Maarel index), b,d,f) number of times that each percentage class of cover was recorded in the quadrats. An asterisk indicates a significant difference between the two stands (Mann-Whitney test; $P$-value $<0.05$ ).
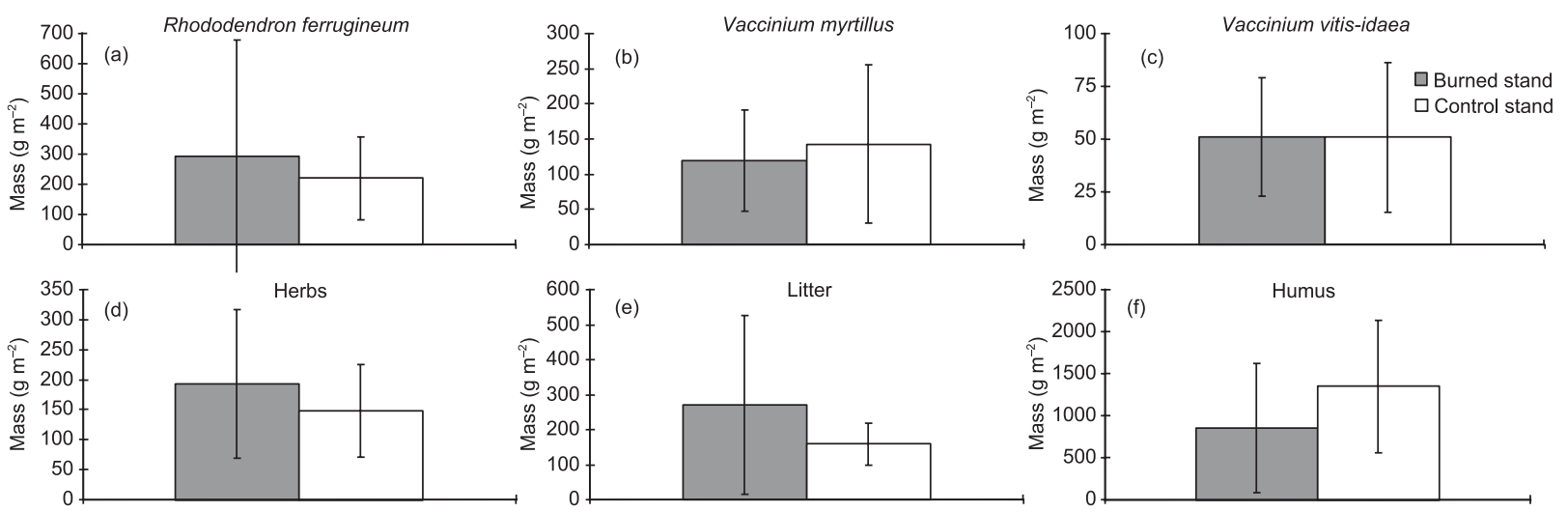

Fig. 7. Dry measured biomass of (a) Rhododendron ferrugineum, (b) Vaccinium myrtillus, (c) Vaccinium vitis-idaea, (d) herbs, (e) litter layer, and (f) humus layer. 

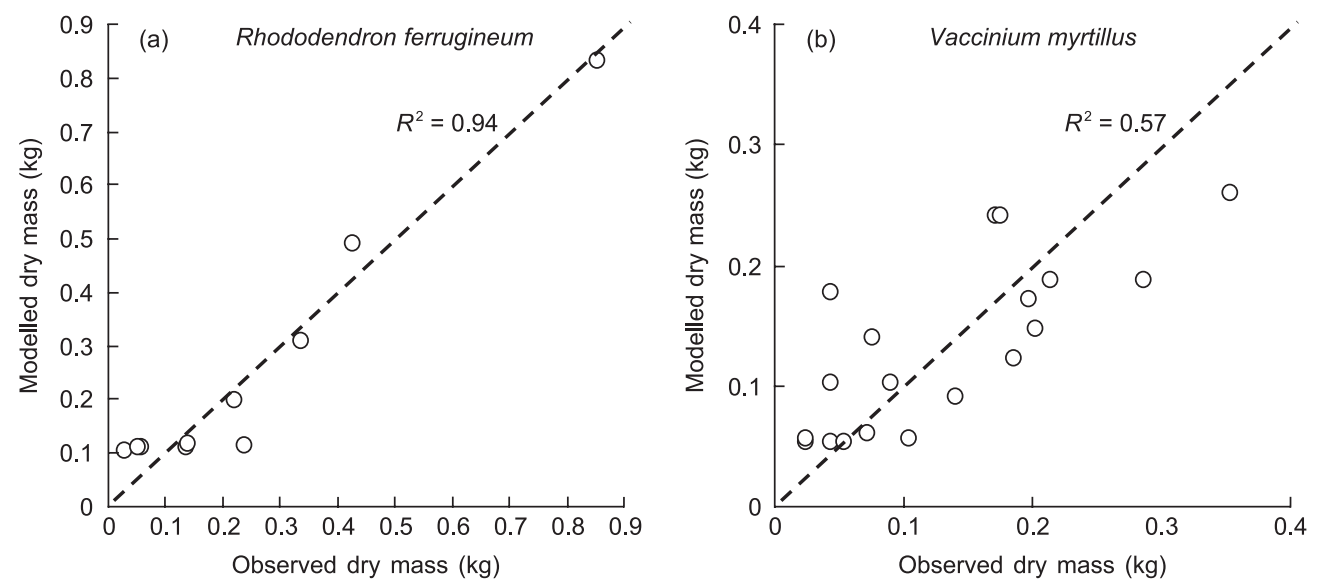

Fig. 8. Correlation between the modelled and the observed dry biomasses of (a) Rhododendron ferrugineum and (b) Vaccinium myrtillus. Both $r^{2}$ values are significant with $P<0.05$.

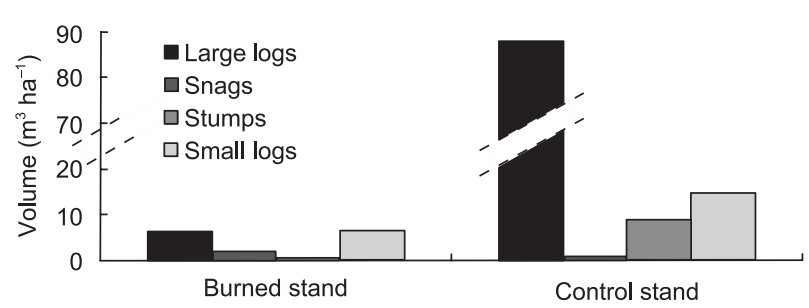

Fig. 9. Volume of coarse woody debris (large logs, snags, stumps and small logs) on the burned and control stands.

Although individuals of L. decidua and P. cembra were found to be of the same age, no scars were found on $L$. decidua. This finding suggests that adult individuals of this species are less sensitive to fire, probably because their thick (> $5 \mathrm{~cm}$ ), non-flammable bark composed of parenchyma rich in water (Hare 1965; Hood et al. 2007) provides efficient fire protection. There are differences in the age structure of the burned and control stands (Fig. 4), with more trees in the burned stand, although the total basal area per stand is similar (Table 2). Table 4 highlights that markedly more trees were cut by humans in the control stand. This difference between the numbers of anthropogenic stumps cannot be explained simply by the greater number of trees in the burned stand. The small number of sawn stumps (54) in both stands compared to the cumulated number of logs (253) and snags (17) also suggests that if cutting activity influenced age structure, it was clearly not the main factor.

The observed tree densities indicate that tree recruitment was more intense in the burned stand. This difference in regeneration could be a result of chemical properties of the soil, which change immediately after burning due to the charcoal load (Nilsson \& Wardle 2005). Indeed, charcoal produced by fires alters the soil nitrogen cycle (Berglund et al. 2004; DeLuca \& Sala 2006) and absorbs phenolic compounds produced by Ericaceous species (Wardle et al. 1998; MacKenzie $\&$ DeLuca 2006). Phenols have numerous functions in soil processes, including limiting nitrification (Hättenschwiler \& Vitousek 2000). By adsorbing phenols, charcoal could have a positive effect on nitrogen availability to young plants, resulting in more regeneration. This ecosystem determinant function of charcoal with respect to the regeneration of L. decidua and P. cembra needs to be tested in light of the specific phenols produced by subalpine Ericaceae, i.e. $R$. ferrugineum and $V$. myrtillus.

Larix decidua and P. cembra each constituted half of the tree populations, thus both have recruited more or less equally since the 17 th century, and their recruitment was not affected by fires. Furthermore, based on the tree age structure, the comparison of the plant biomass (shrubs, herbs) and the necromass (WD), the four fires did not significantly alter the forest community except for $\mathrm{WD}$, which is more abundant in the control stand (Fig. 9).

Surface fires had no effect on $P$. cembra and $L$. decidua population dynamics over the two centuries. However, a positive effect of fire on tree density is indicated by studies in boreal cold conifer forests, where fire represents the main disturbance (e.g. Johnson 1992). It has been shown that with increasing severity of a fire (severe fires involve organic soil combustion), recruitment of trees becomes more important (Johnstone \& Chapin 2006). In our study, this efficient post-fire recruitment is obvious: the density of $P$. cembra seedlings and saplings, accounting for more than $82 \%$ of the total young plants, is higher in the burned than in the control stand (Table 3), although the mean densities of seedlings and saplings are not statistically different between the stands because of high variances (Fig. 5a,b). Pinus cembra seed dispersal is related to the hoarding activity of the European nutcracker (Nucifraga caryocatactes), a bird which caches seeds in open areas (Crocq 1990). The high levels of variability in regeneration may thus illustrate the patchy vegetation cover within the stand after fires, with well-burned patches of a few tens or hundreds of square meters being more attractive to nutcrackers. Moreover, except for the cover values for $V$. vitis-idaea, the cover of the other Ericaceae, the masses of shrubs, herbs, litter layer and humus were not significantly different between the two stands (Table 3; Figs 6 and 7). Finally, the modelled biomass values of $R$. ferrugineum indicate that this species would be 

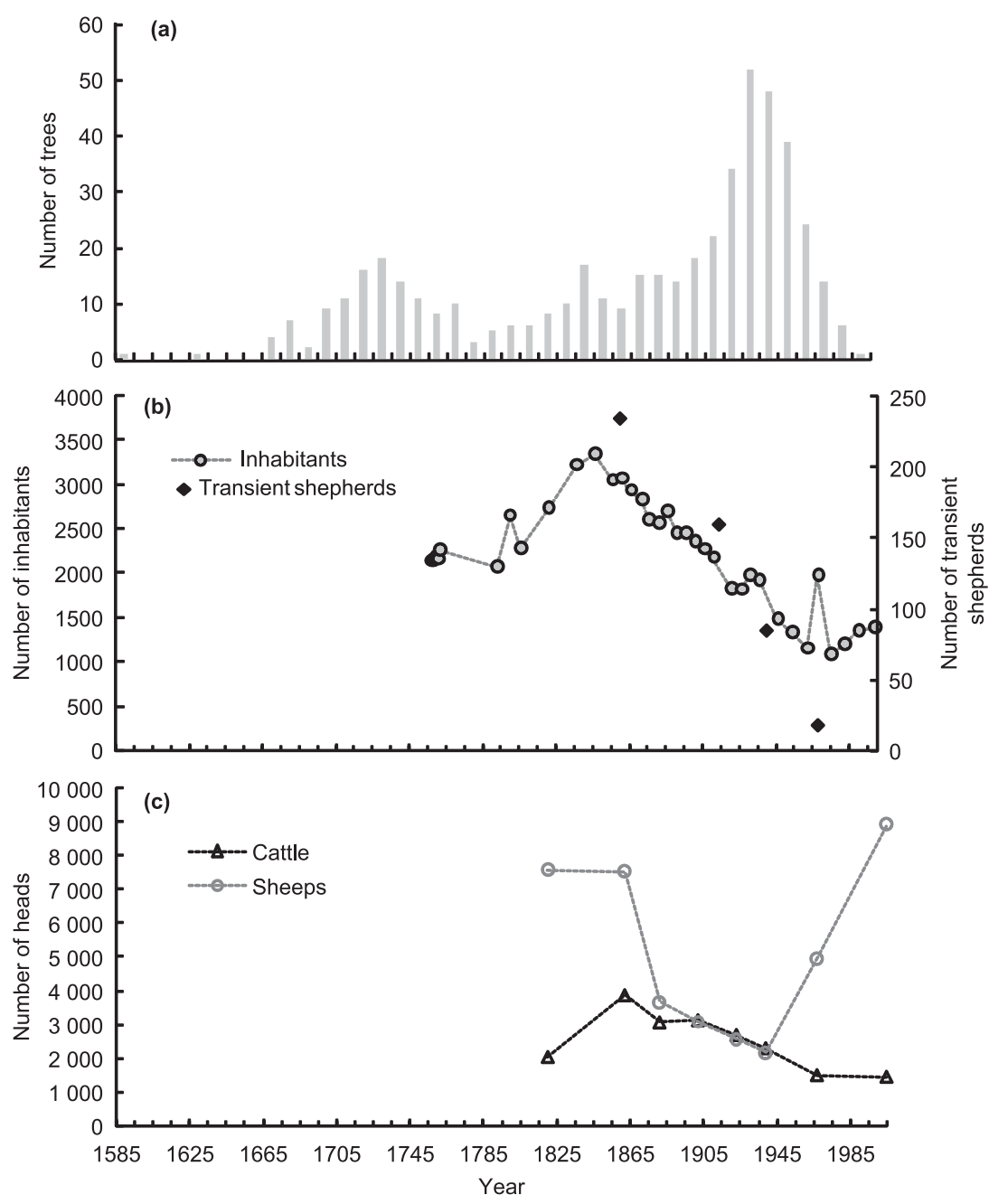

Fig. 10. (a) Cumulated tree age structure per 10-year class; (b) cumulated number of permanent inhabitants and transient shepherds in the three villages closest to the study site (Lanslebourg, Lanslevillard and Bessans); (c) number of cattle and sheep in the upper Maurienne Valley.

more important in the burned stand. This suggests that the poorer recent tree regeneration in the control stand is not the result of competition with shrubs or herbs, neither is it related to the litter and humus depth, but pleads for an effect of repetitive surfaces fires, possibly as a result of their effect on soil chemistry. Furthermore, we did not find evidence of any effect of fire on the species richness of shrubs or herbs (Table 3), although, frequently, disturbances are crucial driving forces for ecosystem processes and biodiversity (White 1979; Frelich 2002) and they have often been found to increase diversity (e.g. Hiura 1995; Glitzenstein et al. 2003). The last fire occurred in 1954, that is, 52 years before our sampling. The effects of fire on understorey species richness are probably not visible after 50 years, which could explain why we were unable to find any difference in species richness between the stands. However, richness and diversity are not necessarily related to the length of time after the fire (Capitanio \& Carcaillet 2008).

Conversely, the impact of the fires on the WD is still visible. The volume of stumps, and large and small downed logs is smaller on the burned stand (Fig. 9), and the proportion of stumps resulting from cutting is insufficient to explain this difference (Table 4). This is probably due to the fact that fires burned the logs and stumps in the forest.
POTENTIAL EFFECTS OF CLIMATE VARIABILITY AND LAND USE ON THE TREE-COMMUNITY

The two stands have followed the same dynamics, as indicated by standardized age-structure analysis (KS-test $P>0.05$; Fig. 4d), although their total tree abundances differ. The similar trends in the population dynamics of L. decidua and P. cembra in the two stands during the 18th and 19th centuries indicate that fire was not the main factor controlling the forest structure and composition; this underlines the role of more regional influences such as land-use or climate variability (Fig. 4).

\section{Climate variability}

Climate data for our study area are very limited, covering the last 50 years at best. Thus, any climatic analysis of tree regeneration is impossible. However, climate reconstructions covering the last 130 years have been undertaken using treerings (Rolland et al. 1998); our age structure data, however, covers more than 300 years (Fig. 4). Although we cannot rule out an effect of climate on tree recruitment, the absence of fine temporal climatic records or reconstructions close to the study site prevents us from analysing the potential effect of 
climate on recruitment. Climate, however, is a key driver of tree recruitment, even when there are frequent fires (Brown \& Wu 2005; Brown 2006).

\section{Land use}

Mountain forests have long been exploited by human population, notably through forestry (direct impact) and livestock grazing (indirect impact). In our study area, $60 \%$ of the tree stumps were created by cutting (Table 4), revealing that timber harvesting occurred recently. In addition, ungulates greatly affect the survival rates of seedlings and saplings in mountain forests through browsing, grazing and trampling (e.g. Ammer 1996; Motta 1996). The Maurienne valley is known to have had an economy based on livestock-breeding activities for centuries (Jail 1969). Livestock could thus have been one factor influencing the vegetation. During the period between 1850 and 1940, tree numbers increased while the number of cattle and sheep decreased, along with numbers of permanent inhabitants and transient shepherds. This could illustrate the severe impact of grazing on tree seedling and sapling survival. Conversely, between 1790 and 1850, and since 1940, all proxies roughly follow the same trends. The decrease in tree abundance since 1950 (Fig. 10a) could be an artefact resulting from the sampling strategy of dating trees with an increment corer: only individuals with a diameter $>5 \mathrm{~cm}$ at $30 \mathrm{~cm}$-high were cored. The mean age of the smallest cored trees indicates that they reach a diameter of $5 \mathrm{~cm}$ at $30 \mathrm{~cm}$-high when they are almost 55 years old. Consequently, this end of the chronology cannot be discussed in the light of land-use changes.

\section{EFFECT OF PASTURE ABANDONMENT ON REGENERATION}

The analysis of the age-class distribution of trees (Fig. 4) shows that, until the 1960s, $P$. cembra and $L$. decidua each represented almost half of the recruited trees, with very few $P$. abies. Since then, with the exception of one $P$. abies, only $P$. cembra is recorded and it continues to regenerate well-enough to be the sole seedling species (Fig. 5).

The reason for this current change in forest composition could be the cessation of grazing almost 50 years ago in the Maurienne Valley, farming having begun to decline as early as 1850 (Fig. 10b,c). Indeed, L. decidua recruitment is affected by thick litter layers, and this species achieves better seedling establishment than P. cembra on the exposed mineral soil created by severe trampling in overgrazed pastures (Risch et al. 2003; Motta et al. 2006b). Although both limited by grazing and forest suppressing, L. decidua establishment would thus have been possible during periods of grazing because $P$. cembra establishment would have been more limited (Motta et al. 2006b; present study). However, since the 1960 s, massive $P$. cembra regeneration has occurred, with severely restricted $L$. decidua recruitment (Figs 4 and 5). The great reduction in grazing pressure after the World War II has resulted in WD accumulation, favouring $P$. cembra; this has occurred in both the French (Eynard-Machet 1994; Wlérick 1994) and the Italian Alps (Motta \& Dotta 1994; Lingua et al. 2008). Decreased livestock grazing in our study area over the last 50 years probably caused the decline in $L$. decidua establishment on abandoned subalpine pastures because of its low competitive ability.

It has been suggested in many recent studies that pure $P$. cembra communities will expand across formerly pure L. decidua or mixed L. decidua $\times$ P. cembra forests (Motta \& Lingua 2005; Schulze et al. 2007; Lingua et al. 2008). These studies suggest that intensive land use for grazing was crucial for $L$. decidua regeneration, and that pure stands of L. decidua will disappear in the near future as a result of large-scale land-use changes in the European mountains unless management is once more intensified to create mineral soil suitable for $L$. decidua regeneration.

\section{WHAT FUTURE LANDSCAPES?}

The abundant recent regeneration of $P$. cembra, together with the lack of $L$. decidua recruitment, could lead to a secondary successional pathway characterized by the progressive replacement of a mixed $L$. decidua $\times P$. cembra community in favour of a pure $P$. cembra community (Motta \& Lingua 2005). Furthermore, one paleoecological study shows that moderate fire regimes did not endanger subalpine ecosystems dominated by $P$. cembra over millennia (Genries et al. 2009 b), thus corresponding to our results covering two centuries. Nevertheless, ongoing climatic changes may lead to an increase in disturbance frequencies (Schär et al. 2004; Schröter et al. 2005; Schumacher \& Bugmann 2006); it has also been shown that high-frequency fires, that is, repetitive fire intervals $<80$ years, could disturb $P$. cembra populations without favouring L. decidua populations (Genries et al. 2009a). Finally, L. decidua seedlings need larger patches caused by severe disturbances, such as clear-cuts, avalanches or flooding, to establish successfully. Studies have also shown that an increase in summer temperature could give $L$. decidua a competitive advantage over $P$. cembra in terms of radial growth if everything else is equal (Anfodillo et al. 1998; Carrer et al. 1999), although all species exhibit increased growth under warmer conditions (Rolland et al. 1998; Carrer \& Urbinati 2004; Carrer et al. 2007). The predicted decrease in precipitation in the Alps (Sheffield \& Wood 2008) could also alter the current trend. It is questionable, therefore, whether the cessation of grazing could confound the eventual effects of climate change.

\section{Conclusion}

The study of a formerly grazed and partially burned forest, affected by surface fires, has provided novel information concerning the role of fire in the dynamics and structure of subalpine forests. The four surface fires in the study area resulted in increased tree density and regeneration. This positive effect could be due to the impact of charcoal on the soil chemistry, a factor that should be examined in the future. 
Nevertheless, our interpretation argues in favour of multiple factors affecting forest structure, including climate variability and, more probably, human land use. Fire probably plays a complementary role in the dynamics of mixed subalpine forests, without altering the tree composition. Conversely, pasture abandonment, which intensified during the 20th century, has a wider impact. Indeed, a decline in L. decidua regeneration is obvious, and pure $P$. cembra stands are expected to be common in the near future.

Nevertheless, pasture abandonment and the lack of current fires favour deadwood accumulation, which could lead to more severe fires in the future. Furthermore, current climatic change could modify this trend by increasing disturbance frequency, with a threshold of fire-intervals that could be lethal for $P$. cembra communities (Genries et al. 2009a). Here, we could not find evidence of any negative effect of fire on the $P$. cembra population in the studied forest, but the four surface fires occurred during a period of only 120 years and mature P. cembra trees probably produce cones over longer periods. We therefore question the ability of such populations to maintain themselves if there were more severe or frequent fires over periods longer than 200 years. The transformation of mixed to pure $P$. cembra forests could be prevented if grazing is restored. This fact highlights the difficulties in assessing the sustainable development of mountain forests and shows that studies are needed to elucidate the relative impacts of climate, disturbances and human practices on long-term vegetation dynamics.

\section{Acknowledgements}

Financial support (to C.C.) was provided by the Institut National des Sciences de l'Univers (INSU-CNRS, France), through the national program ECCO, and by a grant (to A.G.) from the Ministère de l'Enseignement Supérieur et de la Recherche (France). We thank François Bailly, Loïc Bircker, Fanny Combet and Nicole Denis for field or laboratory assistance.

\section{References}

Ammer, C. (1996) Impact of ungulates on structure and dynamics of natural regeneration of mixed mountain forests in the Bavarian Alps. Forest Ecology and Management, 88, 43-53.

Anfodillo, T., Rento, S., Carraro, V., Furlanetto, L., Urbinati, C. \& Carrer, M. (1998) Tree water relations and climatic variations at the alpine timberline: seasonal changes of sap flux and xylem water potential in Larix decidua Miller, Picea abies (L.) Karst. and Pinus cembra L. Annals of Forest Science, 55, 159-172.

Applequist, M.B. (1958) A simple pith locator for use with off-center increment cores. Journal of Forestry, 56, 141.

Arno, S.F. \& Sneck, K.M. (1977) A Method for Determining Fire History in Coniferous Forests of the Mountain West. U.S. Forest Service General Technical Report no. INT-42.

Barbero, M., Bonin, G., Loisel, R. \& Quézel, P. (1990) Changes and disturbances of forest ecosystems caused by human activities in the western part of the Mediterranean Basin. Vegetatio, 87, 151-173.

Bartoli, C. (1966) Etudes écologiques sur les associations végétales forestières de la Haute Maurienne. Annales des Sciences Forestières, 23, 432-751.

Beilhe, F., Carcaillet, C. \& Chauchard, S. (2009) Elévation de la limite supérieure du sapin pectiné (Abies alba Mill.) depuis 1950 en Maurienne, Savoie. Travaux Scientifiques du Parc National de la Vanoise, in press.

Beniston, M. (2000) Environmental Change in Mountains and Uplands. Key Issues in Environmental Change. Arnold, London.

Berglund, L., DeLuca, T.H. \& Zackrisson, O. (2004) Activated carbon amendments to soil alters nitrification rates in Scots pine forests. Soil Biology and Biochemistry, 36, 2067-2073.
Bond, W.J., Woodward, F.I. \& Midgley, G.F. (2005) The global distribution of ecosystems in a world without fire. New Phytologist, 165, 525-538.

Brown, J.K. (1974) Handbook for Inventorying downed Woody Material. USDA Forest Service General Technical Report no. INT-16, Ogden, Utah.

Brown, P.M. (2006) Climate effects on fire regimes and tree recruitment in black hills ponderosa pine forests. Ecology, 87, 2500-2510.

Brown, P.M., \& Wu, R. (2005) Climate and disturbance forcing of episodic tree recruitment in a southwestern ponderosa pine landscape. Ecology, 86, 30303038.

Capitanio, R. \& Carcaillet, C. (2008) Post-fire Mediterranean vegetation dynamics and diversity: a discussion of succession models. Forest Ecology and Management, 255, 432-439.

Carcaillet, C. (1998) A spatially precise study of fires, climate and human impact within the Maurienne valley, North French Alps. Journal of Ecology, 86, 384-396.

Carcaillet, C., Ali, A.A., Blarquez, O., Genries, A., Mourier, B. \& Bremond, L. (2009) Spatial variability of fire history in subalpine forests: from natural to cultural regimes. Ecoscience, 16(1), 1-12.

Carrer, M., \& Urbinati, C. (2004). Age-dependent tree-ring growth responses to climate in Larix decidua and Pinus cembra. Ecology, 85, 730-740.

Carrer, M., Anfodillo, T., Urbinati, C. \& Carraro, V. (1999) High altitude forest trees sensitivity to global warming: results from long-term and short-term analyses in the Italian Eastern Alps. The Impacts of Climate Variability on Forests (eds M. Beninston \& J.L. Innes), pp. 171-189. Springer Verlag, Berlin.

Carrer, M., Nola, P., Eduard, J.-L., Motta, R. \& Urbinati, C. (2007) Regional variability of climate-growth relationships in Pinus cembra high elevation forests in the Alps. Journal of Ecology, 95, 1072-1083.

Chauchard, S., Carcaillet, C. \& Guibal, F. (2007) Patterns of land-use abandonment control tree-recruitment and forest dynamics in Mediterranean mountains. Ecosystems, 10, 936-948.

Chuine, I., Cour, P. \& Rousseau, D.D. (1998) Fitting models predicting dates of flowering of temperate-zone trees using simulated annealing. Plant, Cell \& Environment, 21, 455-466.

Crocq, C. (1990) Le casse-noix moucheté (Nucifraga caryocatactes) (eds Chabaud \& Lechevalier). (Coll.) Monographies Ornithologiques, 326 p.

Delcros, P. (1994) Ecologie du paysage et dynamique végétale post-culturale en zone de montagne. Etudes du CEMAGREF, série Gestion des Territoires $\mathrm{n}^{\circ} 13$, Grenoble, France.

DeLuca, T.H. \& Sala, A. (2006) Frequent fire alters nitrogen transformations in ponderosa pine stands of the inland northwest. Ecology, 87, 25112522.

Didier, L. (2001) Invasion patterns of European larch and Swiss stone pine in subalpine pastures in the French Alps. Forest Ecology and Management, 145, $67-77$.

European Commission DG Environment (2003) Interpretation Manual of European Union Habitats. Eur 25, Brussels, Belgium.

Eynard-Machet, R. (1994) La cartographie historique d'occupation du sol: une méthode pour la visualisation de l'évolution des paysages savoyards par l'intermédiaire des anciens cadastres. L'histoire en Savoie, 7, 11-19.

Frelich, L.E. (2002) Forest Dynamics and Disturbance Regimes. Cambridge University Press, Cambridge.

Gale, J. (1986) Carbon dioxide enhancement of tree growth at high elevations. Science, 231, 859-860.

Gehrig-Fasel, J., Guisan, A. \& Zimmermann, N.E. (2007) Tree line shifts in the Swiss Alps: climate change or land abandonment? Journal of Vegetation Science, 18, 571-582.

Genries, A., Mercier, L., Lavoie, M., Muller, S.D., Radakovitch, O. \& Carcaillet, C. (2009a) The effect of fire frequency on local cembra pine populations. Ecology, 90, 476-486.

Genries, A., Muller, S.D., Mercier, L., Bircker, L. \& Carcaillet, C. (2009b) Fires control spatial variability of subalpine vegetation dynamics during the Holocene in the Maurienne valley (French Alps). Ecoscience, 16, 13-24.

Glitzenstein, J.S., Streng, D.R. \& Wade, D.D. (2003) Fire frequency effects on longleaf pine (Pinus palustris P. Miller) vegetation in South Carolina and northeast Florida, USA. Natural Areas Journal, 23, 22-37.

Grace, J., Berninger, F. \& Nagy, L. (2002) Impacts of climate change on the tree line. Annals of Botany, 90, 537-544.

Graumlich, L.J. (1991) Subalpine tree growth, climate, and increasing $\mathrm{CO}_{2}$ : an assessment of recent growth trends. Ecology, 72, 1-11.

Hare, R.C. (1965) Contribution of bark to fire resistance of southern trees. Journal of Forestry, 63, 248-251.

Hättenschwiler, S. \& Vitousek, P.M. (2000) The role of polyphenols in terrestrial ecosystem nutrient cycling. Trends in Ecology and Evolution, 15, 238243.

Hély, C., Bergeron, Y. \& Flannigan, M.D. (2000a) Coarse woody debris in the southeastern Canadian boreal forest: composition and load variations in 
relation to stand replacement. Canadian Journal of Forest Research, 30, 674 687.

Hély, C., Bergeron, Y. \& Flannigan, M.D. (2000b) Effects of stand composition on fire hazard in the mixed-wood Canadian boreal forest. Journal of Vegetation Science, 11, 813-824.

Hiura, T. (1995) Gap formation and species diversity in Japanese beech forests: a test of the intermediate disturbance hypothesis on a geographic scale. Oecologia, 104, 265-271.

Hood, S.M., McHugh, C.W., Ryan, K.C., Reinhardt, E. \& Smith, S.L. (2007) Evaluation of a post-fire tree mortality model for western USA conifers. International Journal of Wildland Fire, 16, 679-689.

IPCC (2007) Climate Change 2007: The physical science basis. Contribution of Working Group I to the Fourth Assessment Report of the Intergovernmental Panel on Climate Change. Cambridge University Press, Cambridge.

Jail, M. (1969) Recherches sur l'évolution et les problèmes d'une cellule montagnarde intra-alpine. Revue de Géographie Alpine, 57, 85-146.

Johnson, E.A. (1992) Fire and Vegetation Dynamics. Studies from the North American Boreal Forest. Cambridge University Press, Cambridge University. $129 \mathrm{p}$.

Johnstone, J.F. \& Chapin III, F.S. (2006) Effects of soil burn severity on post-fire tree recruitment in boreal forest. Ecosystems, 9, 14-31.

Kajimoto, T., Seki, T., Ikeda, S., Daimaru, H., Okamoto, T. \& Onodera, H. (2002) Effects of snowfall fluctuation on tree growth and establishment of subalpine Abies mariesii near upper forest-limit of Mt Yumori, northern Japan. Artic, Antarctic, and Alpine Research, 34, 191-200.

Krüsi, B.O. \& Moser, B. (2000) Impacts of snow and ungulates on the successional development of a mountain pine forest in the Swiss National Park. Succession Research in the Swiss National Park (eds M. Schütz, B.O. Krüsi \& P.J. Edwards), pp. 131-164. Scientific Council of Swiss National Park, Liestal.

Lingua, E., Cherubini, P., Motta, R. \& Nola, P. (2008) Spatial structure along an altitudinal gradient in the Italian central Alps suggests competition and facilitation among coniferous species. Journal of Vegetation Science, 19, 425-436.

MacKenzie, M. D., \& DeLuca, T.H. (2006) Charcoal and shrubs modify soil processes in ponderosa pine forests of western Montana. Plant Soil, 287, 257-266.

Mast, J.N., Veblen, T.T. \& Linhart, Y.B. (1998) Disturbance and climatic influences on age structure of ponderosa pine at the pine/grassland ecotone. Journal of Biogeography, 25, 743-755.

McRae, D.J., Alexander, M.E. \& Stocks, B.J. (1979) Measurement and Description of Fuels and Fire Behaviour on Prescribed Burns: A Handbook. Canadian Forest Service, Great Lakes Forest Center Inf. Report No. O-X-287.

Metropolis, N., Rosenbluth, A.W., Rosenbluth, M.N. \& Teller, A.H. (1953) Equation of state calculations by fast computing machines. The Journal of Chemical Physics, 21, 1087-1093.

Morin, X., Augspurger, C., \& Chuine, I. (2007) Process-based modeling of tree species' distributions. What limits temperate tree species' range boundaries? Ecology, 88, 2280-2291.

Motta, R. (1996) Impact of wild ungulates on forest regeneration and tree composition of mountain forests in the Western Italian Alps. Forest Ecology and Management, 88, 93-98.

Motta, R. \& Dotta, A. (1994) Some aspects of cembra pine regeneration in the Italian Cottian Alps. Proceedings-International Workshop on Subalpine Pines and Their Environment: the Status of Our Knowledge (eds W. Schmidt \& F.-K. Holtmeier), pp. 254-260. St. Moritz, 1992. USDA Forest Service, Intermountain Research Station, INT-GTR-309, Ogden, Utah.

Motta, R. \& Lingua, E. (2005) Human impact on size, age, and spatial structure in a mixed European larch and Swiss stone pine forest in the Western Italian Alps. Canadian Journal of Forest Research, 35, 1809-1820.

Motta, R., Berretti, R., Lingua, E. \& Piussi, P. (2006a) Coarse woody debris, forest structure and regeneration in the Valbona Forest reserve, Paneveggio, Italian Alps. Forest Ecology and Management, 235, 155-163.

Motta, R., Morales, M. \& Nola, P. (2006b) Human land-use, forest dynamics and tree growth at the treeline in the Western Italian Alps. Annals of Forest Science, 63, 739-747.

Mourier, B. (2008) Contribution de l'approche sédimentaire à la reconstruction de l'histoire des sols - définition de traceurs pédologiques et application sur des sédiments lacustres de montagne (Maurienne, Savoie, France). PhD Thesis, Université de Savoie, Chambéry.

Nilsson, M.C. \& Wardle, D.A. (2005) Understory vegetation as a forest ecosystem driver: evidence from the northern Swedish boreal forest. Frontiers in Ecology and the Environment, 3, 421-428.

Piussi, P. (1994) Mixed cembran pine stands on the southern slope of the Eastern Alps. Proceedings-International Workshop on Subalpine Pines and Their Environment: the Status of Our Knowledge (eds W. Schmidt \& F.-K. Holtmeier), pp. 261-268. St. Moritz, 1992. USDA Forest Service, Intermountain Research Station, INT-GTR-309, Ogden, Utah.

Price, M.F. (2003) Why mountain forests are important. Forestry Chronicle, 79, 219-222.

Risch, A.C., Nagel, L.M., Schütz, M., Krüsi, B.O., Kienast, F. \& Bugmann, H. (2003) Structure and long-term development of subalpine Pinus montana Miller and Pinus cembra L. forests in the Central European Alps. Forstwissenschaftliches Centralblatt, 122, 219-230.

Rolland, C. Petitcolas, V. \& Michalet R. (1998) Changes in radial tree growth for Picea abies, Larix decidua, Pinus cembra and Pinus uncinata near the alpine timberline since 1750. Trees-Structure and Function, 13, 4053.

Schär, C., Vidale, P.L., Lüthi, D., Frei, C., Häberli, C., Liniger, M.A. \& Appenzeller, C. (2004) The role of increasing temperature variability in European summer heatwaves. Nature, 427, 332-336.

Scheller, R.M. \& Mladenoff, D.J. (2005) A spatially interactive simulation of climate change, harvesting, wind, and tree species migration and projected changes to forest composition and biomass in northern Wisconsin, USA. Global Change Biology, 11, 307-321.

Schröter, D., Cramer, W., Leemans, R., Prentice, I.C., Araujo, M.B., Arnell, N.W., et al. (2005) Ecosystem service supply and vulnerability to global change in Europe. Science, 310, 1333-1337.

Schulze, E.-D., Mischì, G., Asche, G. \& Börner, A. (2007) Land-use history and succession of Larix decidua in the Southern Alps of Italy-An essay based on a cultural history study of Roswitha Asche. Flora, 202, 705-713.

Schumacher, S. \& Bugmann, H. (2006) The relative importance of climatic effects, wildfires and management for future forest landscape dynamics in the Swiss Alps. Global Change Biology, 12, 1435-1450.

Sheffield, J., \& Wood, E.F. (2008) Projected changes in drought occurrence under future global warming from multi-model, multi-scenario, IPCC AR4 simulations. Climate Dynamics, 31, 79-105.

Thuiller, W., Lavorel, S., Araujo, M.B., Sykes, M.T. \& Prentice, I.C. (2005) Climate change threats to plant diversity in Europe. Proceedings of the National Academy of Sciences of USA, 102, 8245-8250.

Tinner, W., Hubschmid, P., Wehrli, M., Ammann, B. \& Conedera, M. (1999) Long-term forest fire ecology and dynamics in southern Switzerland. Journal of Ecology, 87, 273-289.

Van der Maarel, E. (1979) Transformation of cover-abundance values in phytosociology and its effects on community similarity. Vegetatio, 39, 97-114.

Van Wagner, C.E. (1982) Practical Aspects of the Line Intersect Method. Canadian Forest Service, Petawawa National Forest Inst. Inf. Report No. PI-X-12.

Wardle, D.A., Zackrisson, O. \& Nilsson, M.-C. (1998) The charcoal effect in Boreal forests: mechanisms and ecological consequences. Oecologia, 115, 419-426.

White, P.S. (1979) Pattern, process, and natural disturbance in vegetation. Botanical Review, 45, 229-299.

Wlérick, L. (1994) The cembra pine in the French Alps: stand dynamics of a cembra pine forest in Tueda (Savoy, France). Proceedings-International Workshop on Subalpine Stone Pines and Their Environment: the Status of Our Knowledge (eds W.C. Schmidt \& F.K. Holtmeier), pp. 280-288. St. Moritz, 1992. USDA Forest Service, Intermountain Research Station, INT-GTR309, Ogden, Utah.

Wright, H.E. (1974) Landscape development, forest fires, and wilderness management. Science, 186, 487-495.

Received 12 March 2009; accepted 9 April 2009

Handling Editor: Richard Bradshaw 